\title{
Impact of Micro-Credit on Economic Empowerment of Rural Women
}

\author{
S. Sultana ${ }^{1}$ and S. S. Hasan ${ }^{2 *}$ \\ ${ }^{1}$ ATI, Gazipur, Bangladesh \\ ${ }^{2}$ Department of Agricultural Extension \& Rural Development, Banagabandhu Sheikh Mujibur Rahman \\ Agricultural University, Gazipur-1706, Bangladesh. \\ *Corresponding author and Email: shinuextn120@yahoo.com
}

Received: 31 October 2010

Accepted: 17 March 2011

\begin{abstract}
The study was undertaken to analyze the impact of micro-credit on rural women's economic empowerment. The study was conducted in Bariyali, Teknogpara and Naga villages of Basan and Kayaltia union under Gazipur Sadar Upazila of Gazipur District. A total number of 90 respondents were selected as sample using stratified rndom sampling technique. Out of 90 respondents, 45 women were involved with Bangladesh Rural Advancement Committee (BRAC) micro-credit program. Other 45 women had no involvement with any other micro-credit programs and they belonged to control group. Both these two groups had same socio-demographic characteristics. Survey method was applied and interview schedule was used to collect relevant data from the respondents. For measuring economic empowerment of rural women, three economic indicators ie., personal income, savings behavior and assets ownership were considered and sample t- test was performed to evaluate the impact of micro-credit on economic empowerment. Results of this study indicated significant differences between BRAC and non BRAC women regarding all these economic indicators of empowerment. In all the cases, BRAC women were more economically empowered than those of non BRAC women. It was also found that BRAC women had more active participation in various income generating activities. The study also revealed that the BRAC women received more micro-credit and utilized this for conducting more income generating activities than control group. They earned more income, saved more money and at the same time owned more assets than non BRAC women. The study stressed the need of more loans to be expanded to low income women folk by different GO and NGOs which would ultimately enhance their economic solvency and empower them economically. This would obviously be helpful for the upliftment of the rural women socio-economically.
\end{abstract}

Keywords: Rural women, micro-credit, impact, empowerment

\section{Introduction}

Bangladesh is a rural and agrarian country having a population of 15 million (Anonymous, 2007). Rural development in general and agricultural development in particular, through men and women participation, is the most important strategy designed to improve the social and economic life of the farming community in Bangladesh. However empowerment of rural women uplifts their capacity to participate into socioeconomic activities, decision making and poverty alleviation and ultimately improve their livelihood situation (Basher, 2007).
Women in Bangladesh suffer from multiple deprivations in social and economic spheres of their life due to patriarchal values prevalent in the society. Most of the women live in rural areas of Bangladesh, where majority of them play a major role in the areas of management of crops, livestock, fisheries, biological diversity, energy and family. Even though the economic contribution of rural women is substantial, it is largely unacknowledged. In addition to their productive work, the traditional division of labor gives women the primary responsibility for such domestic chores as cleaning, cooking, childcare, fetching water and so on. Women's limited 
access to markets, economic services, education, health care and politics leads to a lower wellbeing of the family that retards the developmental goals of the state and traumatize women (Parveen and Chaudhury, 2009).

Individuals acquiring the power to think and act freely, to exercise choice and fulfill their potential as full and equal members of society. Women's empowerment is a process of transforming gender relations through groups or individuals by developing awareness of women's subordination and building the capacity to challenge it. The empowerment of women is an essential precondition for the alleviation of poverty and the upholding of human rights, in particular at the individual level, as it helps to build a base for social change (DFID, 2006). Empowerment is, thus, a process of changing the power potential within an individual first and consequently a change of relationships at different groups and societal levels. These changes have to be permanent and thus necessitate constant efforts over a long period of time. Musokotwane et. al., 2001 defined empowerment of women as a process through which women and men in disadvantaged positions increase their access to knowledge, resources, decision-making power and raise their awareness of participation in their own communities in order to have control over their own environments.

Micro-credit has come a long way since its start by Professor Yunus, Managing Director of Grameen Bank, in 1974 in Jobra, a village in Chittagong of Bangladesh. The strength of micro-credit lies in its ability to organize idle women into a productive workforce with their proven creditworthiness (Chavan and Ramakumar, 2002). Micro-credit has been claimed to be a solution to most of the problems that originated out of the state's efforts to alleviate poverty and women empowerment by using the instrument of credit. Micro-credit plays an important role for accelerating economic growth in any developing country. It is believed that 25 million people worldwide are now using micro-credit to undertake income-generating or self-employment activities; of these, $90 \%$ are women. Micro-credit has not only made women more productive, it has also empowered them (Chavan and Ramakumar, 2002). Micro-credit is a system of small loans for income-generating activities, which enable poor communities to gain some economic stability. The system is carefully planned to provide people with the resources they need to improve their economic status, without encouraging debt. Micro credit is one of the most important factors for enhancing socio-economic development of the rural poor. Besides, GOs, NGOs play the most important role in distributing micro credit to clientele to overcome poverty and helping the poorer sector to uplift their situations that are living below the poverty line. Micro credit is considered now not merely an instrument for credit extension to the poor borrowers but also a movement to emancipate the poor--especially women--to alleviate their poverty, improve their quality of life, build their capacity and awareness, to integrate them economically and socially into the mainstream of the economy.

So access to micro-credit is one of the very important components in empowering income for poor women. But very few studies have so far been focused on micro-credit's impact on women's empowerment specifically on economic empowerment in Bangladesh. Keeping these views in mind, this study was undertaken considering the following objectives: i) To determine and describe some selected characteristics of rural women, and ii) To find out the impact of micro credit on rural women's empowerment on economic dimensions in the study area.

\section{Methodology}

The study was undertaken in Bariyali, Teknogpara and Naga villages of Basan and Kayaltia union under Gazipur Sadar Upazila of Gazipur District. A total of 90 respondents were selected using stratified random sampling 
technique, out of which 45 were involved in the credit program of BRAC and other 45 women had no involvement in any credit program and they were considered as control group. Both BRAC group and control group had a similar socioeconomic status. Three indicators such as personal income, yearly savings and asset ownership were considered to measure women's economic empowerment.

Survey method was applied throughout the study. For collecting relevant data form the respondents, an interview schedule was prepared considering the objectives in view. Personal interview was conducted with all the 90 respondents using this interview schedule. Simple statistics like percentage, mean, range etc were calculated and at the same time sample ttest was performed for evaluating the impact of micro-credit on the empowerment of rural women.

\subsection{Measurement of variables}

Age, education, number of children, family size, family farm size, and credit received were considered as the independent variables of the study. Age of the respondents was measured in terms of years on the basis of her response. A score of one was assigned for each year of her age. Similarly 1 for each number of child. A score of one (1) was given to a respondent who has completed one year of schooling. A score of zero (0) was assigned to an illiterate respondent who cannot read and write at all. A respondent who could sign his/ her name only, his/her educational qualification was considered equal to one year of schooling and was given a score of one. Family size included all members of a household like husband, wife, children and other members who are living together in a family. Family size of a respondent could be measured by assigning a score of one (1) for each member of the family. Family farm size was estimated on the basis of the cultivated area either owned by a farmer or cultivated on share cropping, the area being estimated in terms of full benefit to the respondents. The total area of land thus obtained was considered as the farm size score of the respondent. Credit received was measured to the amount of money received by a respondent as loan from any institutional source or noninstitutional source. It was expressed in Taka.

Women economic empowerment was considered as the dependant variable of the study. This economic empowerment was measured in three dimensions and these were measured through personal income, savings behavior and ownership of assets. Personal income of the respondents was measured in terms of money (taka) generated annually. Both farm (crops, vegetables, poultry, livestock, fisheries, etc) and non-farm income sources (small business, services and handicrafts etc) were considered in measuring annual personal income of the respondents. Savings of the respondents was measured in terms of money (taka) saved annually. Different forms of savings, such as cash savings at home, savings as crops, savings in NGOs or rural co-operatives and savings in bank were considered in measuring savings of the respondents. Asset of the respondents was measured in terms of money (taka) value of the assets at the time of interview. Both productive (cattle, goat and poultry) and non-productive (jewellery, TV/ radio and small vehicle and others) assets were taken into consideration in measuring the value of asset of the respondents.

\section{Results and Discussion}

\subsection{Personal characteristics of the respondents}

According to Table 1, average age of the respondents was 34.74 years as the observed range of age of the respondents was 21-50 years. The respondents had an average education rate at primary level. The literacy of the farmers is an important factor, which determines their communication behavior. More particularly, it allows one to have access to the printed media. But the picture of education of the study area was unsatisfactory. 
Table 1. Summary of personal characteristics of the respondents

\begin{tabular}{lll}
\hline Variables (unit) & Mean & Observed range \\
\hline Age (years) & 34.74 & $21-50$ \\
Education & 5.09 & $0-14$ \\
Number of children (number) & 3.0 & $0-8$ \\
Family size (number) & 5.66 & $3-12$ \\
Family farm size (hectares) & 0.26 & $0.02-1.05$ \\
Credit received (taka) & 16155.56 & $5000-70000$ \\
\hline
\end{tabular}

Table 2. Personal annual income of the respondents (BRAC and non BRAC)

\begin{tabular}{l|c|c}
\hline Income source & Average in taka (BRAC) & Average in taka (Non BRAC) \\
\hline Vegetables & 803.13 & 293.33 \\
Poultry & 3339.19 & 570.45 \\
Small business & 1120.00 & 244.44 \\
Service & 10178.57 & 7444.44 \\
Handicrafts & 2209.68 & 1662.79 \\
Total & 12050.00 & 10102.79 \\
\hline
\end{tabular}

On an average the respondents had 3 children but the average family size was 5.66 . Their average farm size was 0.26 hectares. Hoque and Itohara (2008) in their study showed that farm size played a vital role of rural women for their empowerment and it influenced all other variables.

\subsection{Dimensions of Economic Empowerment}

Data contained in Table 2 indicate that the respondents who were involved with BRAC micro-credit earned an average amount of 803 taka compared to those women who were not involved with any organization or did not take micro-credit earned only 293 taka from vegetables. Income from poultry birds was also an important source of annual personal income. BRAC women earned an average of taka 3339 from poultry birds but non BRAC women earned only taka 570 from poultry birds. Among the non farm personal income sources, service was the main income source (for BRAC women it was taka 10178 and for non BRAC women it was taka 7444) followed by handicrafts production (for BRAC women 2209 taka and for non BRAC women 1662 taka) and small business (for BRAC women 1120 taka and non BRAC women 244 taka).
It was clear from Table 2 that in every source of personal income the women who were involved with BRAC micro-credit program earned more than those of the women who were not involved with any other micro-credit program. A study conducted by Parvin et. al., 2004 also showed that all the personal income from different income sources enabled women to have better access to basic needs and make important contribution to household decision making which ultimately had positive impact on women empowerment.

Data presented in Table 3 show the savings pattern of the respondents from different sources indicate clearly that the respondents' saving money in bank (BRAC women 5160 taka and non BRAC women 4784 taka) were followed by savings as crops (BRAC women 2371 taka and non BRAC women 855 taka), cash savings on hand (BRAC women 2271 taka and non BRAC women 1071 taka). In case of total amount of savings the women involved with BRAC microcredit programs saved more money (11143 taka) annually than those of the women who were not involved with any micro-credit programs (7275.56 taka). 
Table 3. Amount of yearly savings of the respondents from different sources

\begin{tabular}{lll}
\hline Saving source & Average in taka (BRAC) & Average in taka (Non BRAC) \\
\hline Cash savings on hand & 2277.78 & 1071.11 \\
Savings as crops & 2371.11 & 855.56 \\
Savings in NGO & 1356.44 & 558.13 \\
Savings in Bank & 5160.00 & 4784.44 \\
Total & 11143.11 & 7275.56 \\
\hline
\end{tabular}

Table 4. Assets owned by the respondents

\begin{tabular}{lcc}
\hline Types of assets & Average in taka (BRAC) & Average in taka (Non BRAC) \\
\hline Productive & & \\
Cattle & 1933.33 & 1222.22 \\
Goat & 340.00 & 135.56 \\
Poultry & 351.11 & 403.33 \\
Non productive & & \\
Jwellery & 2288.89 & 2068.18 \\
TV/Radio & 2688.89 & 2930.23 \\
Small vehicle & 466.67 & 1566.67 \\
Total & 20607.77 & 16382.32 \\
\hline
\end{tabular}

Savings are an effective weapon against economic shocks. This is a positive expedition towards development. NGOs are playing vital and praise worthy role in creating saving habit among the rural poor people which was also clear from Table 3. The respondents used the savings during household risks, children's education and purchasing assets.

From Table 4, it was clear that the respondents owned both productive assets and nonproductive assets. Productive assets included in the study area were cattle, goat, poultry, etc. Non productive assets of rural women included jewelries, TV/radio, small vehicles and others households goods.

The average value of productive assets owned by the women involved with BRAC micro-credit program was cattle 1933 taka, poultry 351 taka, goat 340 taka and the average value of productive assets owned by the women who were not involved with any micro-credit program was cattle 1222 taka, poultry 403 taka and goat
135 taka. On the other hand, the average value of non productive assets owned by the respondents were jewelry (BRAC women approximately 2289 taka and non BRAC women 2068 taka), TV/Radio (BRAC women 2689 taka and non BRAC women 2930 taka) and small vehicle (BRAC women 467 taka and non BRAC women 1567 taka). It was found from Table 4 that in total BRAC women owned more assets (approximately 20608 taka) than those of non BRAC women (16382 taka). Some studies conducted earlier, showed that women's asset ownership positively influenced their empowerment at household level and reduced their vulnerability in several ways (Hossain et al., 2004). It was suggested that women's involvement group savings and credit programs act as the driving force to help illiterate rural women start small-scale economic activities (Acharya et. al., 2007). It strengthens coping mechanisms during crisis, diversify income generation, build assets and improve the status of women (Hashemi et. al., 1996). 
Table 5. Comparison of economic empowerment between BRAC and Non BRAC women

\begin{tabular}{l|l|l}
\hline Category & Mean & F- Static \\
\hline BRAC women $(\mathrm{n}=45)$ & 5.51 & \\
Non BRAC women $(\mathrm{n}=45)$ & 4.61 & $5.283^{*}$ \\
Total & 5.09 & $(P=0.05)$ \\
\hline
\end{tabular}

* Means significant at 5\% level

\subsection{Impact of micro-credit on economic empowerment of women}

It is depicted in Table 5 that the mean value of BRAC women's economic empowerment varies significantly from those of non BRAC women group and the F-statistic was significant at $5 \%$ level $(\mathrm{F}=5.283)$. This means that the level of economic empowerment of BRAC women was more than those of non BRAC women.

In most of the cases BRAC women earned more because they were more active to participate in income generating activities of various types. Economically solvent people can perform better while exercising his/her power. Solvency or economic condition of any people is an important parameter of empowerment. This statement was absolutely true for the BRAC women group compared to non BRAC women group as BRAC women were more empowered due to their economic solvency. The findings of the study of Parveen and Chaudhury (2009) also supported this result. In another study, Amin and Pebley (1994) found that membership in BRAC positively influenced women's decision making role, her control over resources and mobility.

\section{Conclusions}

From the findings and discussion mentioned above, it can be concluded that most of the rural women had a very low level of education ie., primary level of education with an average family size of 5.66, and an average farm size of 0.26 hectares. The respondents received a total amount of 16155 taka annually as credit which they could utilize for performing different types of income generating activities. They deposited money mainly in banks. Personal annual income of BRAC women was more than those of non BRAC women. The rural women possessed both productive and non productive assets. This savings and assets helped them as a protection against household risks. Satisfactory differences were found between BRAC women and nonBRAC women in their level of economic empowerment. It was concluded that women having involvement with BRAC acquired more knowledge about health, agriculture, nutrition and got loan to utilize in various income generating activities for earning more income. As a result, they could uplift themselves socioeconomically. This study also provides evidence that economic empowerment of women can be improved through increasing personal income, savings and assets.

\section{References}

Amin S and Pebley, A .1994. Gender Inequality within Households: The impact of a women's development programme in 36 Bangladeshi villages. The Bangladesh Development Studies - Special Issue on Women, Development and Change, XXII (2\&3): 121-155.

Annonymous. 2007. Bangladesh Bureau of Statistics. Ministry of Planning, Government of People's Republic of Bangladesh, Dhaka, Bangladesh, 7 p.

Acharya, S., Yoshino, E., Jimba, M. and Wakai, S. 2007. Empowering rural women through a community development approach in Nepal. Community Development Journal, 42 (1): 34-46 pp.

Basher, M. A. 2007. Empowerment of microcredit participants and its spillover effects: evidence from the Grameen Bank of 
Bangladesh. Journal of Developing Areas, 40(2): 173-183 pp.

Chavan, P. and Ramakumar, R. 2002. "MicroCredit and Rural Poverty: An Analysis of Empirical Evidence". Proc. of the Economic and Political Weekly, March, 2002.

DFID. 2006. Evaluation of DFID's Policy and Practice in Support of Gender Equality and Women's Empowerment. Evaluation Report EV669, III: 61-62 pp.

Hashemi S, Schuler, S and Riley, R.1996. Rural Credit Programs and Women's Empowerment in Bangladesh. World Development, 24 (4): 635-653 pp.

Hossain, M., Paris, T.R., Bose, M.L. and Chowdhury, A. 2004. Nature and Impact of Women's Participation in Economic Activities in Rural Bangladesh. Proc. of the CPD-IRRI Policy Brief. Centre for Policy Dialogue, Dhaka.

Hoque, M. and Itohara, Y. 2008. Participation and decision making role of rural women in economic activities: A comparative study for members and non members of the micro-credit organizations in Bangladesh. Journal of Social Science, 4(3): 231-238.

Musokotwane, R., Siwale, R.M. and Nkhata, B. 2001. Gender Awareness and Sensitization in Basic Education. Proc. of People's Action Forum UNESCO Basic Education.

Parveen, S. and Chaudhury, M.S.R. 2009. Micro-credit intervention and its effect on empowerment of rural women: The BRAC experience. Bangladesh Research Publication Journal, 2(3): 641-647.

Parvin, G. A.; Ahsan, S.M. R.and Chowdhury, M. R. 2004. Women Empowerment Performance of Income Generating Activities Supported by Rural Women Employment Creation Project (RWECP): A Case Study in Dumuria Thana, Bangladesh. The Journal of GeoEnvironment, 4: 47-62. 